\title{
Antioxidant and Cytotoxic Activities of Usnea barbata (L.) F.H. Wigg. Dry Extracts in Different Solvents
}

\author{
Violeta Popovici ${ }^{1}$, Laura Bucur ${ }^{2, *}$, Antoanela Popescu ${ }^{2}$, Verginica Schröder ${ }^{3}{ }^{\oplus}$, Teodor Costache ${ }^{4}{ }^{\oplus}$, \\ Dan Rambu ${ }^{4}$, Iulia Elena Cucolea ${ }^{4}$, Cerasela Elena Gîrd ${ }^{5}{ }^{\oplus}$, Aureliana Caraiane ${ }^{6}$, Daniela Gherghel ${ }^{7}$, \\ Gabriela Vochita ${ }^{7}$ and Victoria Badea ${ }^{1}$
}

check for

updates

Citation: Popovici, V.; Bucur, L.; Popescu, A.; Schröder, V.; Costache, T.; Rambu, D.; Cucolea, I.E.; Gîrd, C.E.; Caraiane, A.; Gherghel, D.; et al. Antioxidant and Cytotoxic Activities of Usnea barbata (L.) F.H. Wigg. Dry Extracts in Different Solvents. Plants 2021, 10, 909. https://doi.org/ $10.3390 /$ plants10050909

Academic Editor:

Katarzyna Szewczyk

Received: 6 April 2021

Accepted: 30 April 2021

Published: 1 May 2021

Publisher's Note: MDPI stays neutral with regard to jurisdictional claims in published maps and institutional affiliations.

Copyright: (c) 2021 by the authors. Licensee MDPI, Basel, Switzerland. This article is an open access article distributed under the terms and conditions of the Creative Commons Attribution (CC BY) license (https:// creativecommons.org/licenses/by/ $4.0 /)$.
1 Department of Microbiology and Immunology, Faculty of Dental Medicine, Ovidius University of Constanta, 7 Ilarie Voronca Street, 900684 Constanta, Romania; violeta.popovici@365.univ-ovidius.ro (V.P.); victoria.badea@365.univ-ovidius.ro (V.B.)

2 Department of Pharmacognosy, Faculty of Pharmacy, Ovidius University of Constanta, 6 Capitan Al. Serbanescu Street, 900001 Constanta, Romania; antoanela.popescu@365.univ-ovidius.ro

3 Department of Cellular and Molecular Biology, Faculty of Pharmacy, Ovidius University of Constanta, 6 Capitan Al. Serbanescu Street, 900001 Constanta, Romania; verginica.schroder@univ-ovidius.ro

4 Research Center for Instrumental Analysis SCIENT, 1E Petre Ispirescu Street, 077167 Ilfov, Romania; teodor.costache@scient.ro (T.C.); dan.rambu@scient.ro (D.R.); iulia.cucolea@scient.ro (I.E.C.)

5 Department of Pharmacognosy, Phytochemistry, and Phytotherapy, Faculty of Pharmacy, Carol Davila University of Medicine and Pharmacy, 6 Traian Vuia Street, 020956 Bucharest, Romania; cerasela.gird@umfcd.ro

6 Department of Oral Rehabilitation, Faculty of Dental Medicine, Ovidius University of Constanta, 7 Ilarie Voronca Street, 900684 Constanta, Romania; aureliana.caraiane@365.univ-ovidius.ro

7 Institute of Biological Research Iasi, Branch of NIRDBS, 47 Lascar Catargi Street, 700107 Iasi, Romania; daniela.gherghel@icbiasi.ro (D.G.); gabriela.vochita@icbiasi.ro (G.V.)

* Correspondence: laura.bucur@univ-ovidius.ro; Tel.: +40-721528446

Abstract: Lichens represent a significant source of antioxidants due to numerous metabolites that can reduce free radicals. Usnea barbata (L.) F.H. Wigg. has been recognized and used since ancient times for its therapeutic effects, some of which are based on its antioxidant properties. The present study aims to analyze the phytochemical profile and to evaluate the antioxidant and cytotoxic potential of this lichen species. Five dry extracts of $U$. barbata (UBDE) in different solvents (acetone, ethyl acetate, ethanol, methanol, water) were prepared by refluxing at Soxhlet to achieve these proposed objectives and to identify which solvent is the most effective for the extraction. The usnic acid content (UAC) was quantified by ultra-high performance liquid chromatography (UHPLC). The total polyphenols content (TPC) and tannins content (TC) were evaluated by spectrophotometry, and the total polysaccharides (PSC) were extracted by a gravimetric method. The 2,2-diphenyl-1-picrylhydrazyl-hydrate (DPPH) free radical method was used to assess the antioxidant activity (AA) and the Brine Shrimp Lethality (BSL) assay was the biotest for cytotoxic activity evaluation. The ethyl acetate extract had the highest usnic acid content, and acetone extract had the highest content of total polyphenols and tannins. The most significant antioxidant effect was reported to methanol extract, and all the extracts proved high cytotoxicity. The water extract has the lowest cytotoxicity because usnic acid is slightly soluble in this solvent, and it was not found at UHPLC analysis. All extracts recorded a moderate correlation between the content of usnic acid, polyphenols, tannins, and AA; furthermore, it has been observed that the cytotoxicity varies inversely with the antioxidant effect.

Keywords: U. barbata; usnic acid; UHPLC; polyphenols; tannins; polysaccharides

\section{Introduction}

In the confrontation with illness, the human body is far from well-protected. Once installed at the molecular level, an imbalance [1] can sooner or later generate disease, and the human body could be hardly recovered. Not only that: it is increasingly challenging to 
avoid internal or external factors that expose the body to these imbalances, which generate the well-known oxidative stress [2]. Environmental pollution [3], heavy metals, xenobiotics, ultraviolet light [4], immune cell activation, inflammation [5], and mental stress [6] lead to excessive reactive oxygen and nitrogen species (ROS and RNS) [7]. They generate oxidative destruction of cellular macromolecules (nucleic acids, proteins, carbohydrates, lipids). The body antioxidant defense is no longer coping, and these reactive species negatively affect the cell structures, producing complex changes that generate premature ageing [8] and numerous diseases [9]. Current research in the medical world is focused on finding new organic compounds with an antioxidant role, protecting the human body against free radicals [10].

It is known that ROS and RNS are permanently generated in plants as a result of aerobic metabolism; some of these reactive species have high toxicity, and the numerous cellular mechanisms rapidly neutralize them [11]. Various plant extracts [12] and isolated natural compounds [13] have antioxidant effects: vitamins [14], flavonoids [15], polyphenols [16], sterols [17], and polysaccharides [18]. Lichens are a significant source of antioxidants [19]; the Parmeliaceae family [20] with the Usnea genus, are known due to their antioxidant metabolites [21]. The present study is performed on $U$. barbata (commonly called Old Man's Beard, and also named Song Luo in China), a lichen used for over 2000 years in Chinese traditional medicine for its therapeutic properties. Its phytochemical profile consists of primary metabolites (fatty acids and lichen polysaccharides as lichenan, homoglucan) and specific secondary metabolites. This last category, named lichen secondary metabolites, consists of specific phenolic compounds (depsides, depsidones) [22] (p. 603), dibenzofurans (usnic acid), and diphenyl-ethers [23]. These organic constituents are the results of the special structure of lichens, represented by the symbiosis between fungus and algae (cyanobacteria) [24]. Usnic acid is the most significant secondary metabolite of the genus Usnea, with various biological activities: antioxidant, gastroprotective, cytoprotective, immunostimulatory, antimicrobial, anti-inflammatory, and antitumor [25]. The aim of this study is to perform a comparative analysis of five UBDE obtained using different solvents. We highlighted their phytochemical profile determining the content of usnic acid [26], polyphenols [27], tannins [28], and polysaccharides [29]—all these classes of organic compounds being recognized due to their antioxidant properties. The antioxidant activity of UBDE was evaluated and correlated with UAC, TPC, and TC.

In other circumstances, plants appear to generate ROS as signaling molecules to control various processes, including pathogen defense and programmed cell death [11]. For this reason, the last part of our study consists of analyzing the cytotoxic action of all five extracts; we also included in this study usnic acid because it has a dual role in redox processes [30]. The effects of UBDE were evaluated using Artemia sp. (also named brine shrimp) bio-tester organisms, BSL assay [31], used for the pre-screening of plant extracts cytotoxicity [32]. The BSL assay represents a significant step before modelling in pharmaceutical research [33]. Our previous studies on UBDE in acetone proved in vivo cytotoxic effects on Artemia sp. larvae and in vitro antitumor activity on human tongue squamous cells carcinoma (CAL 27 cell line) by involving the apoptotic mechanism [34]. U. barbata dry extract in acetone has a high UAC, and usnic acid induces ROS-dependent apoptosis of tumor cells $[35,36]$.

The biological activity of different species of lichens is a consequence of the natural mixtures of compounds and, also of their interactions. This study analyzed the variable results obtained for each extract, correlating them with the chemical constituents extracted by each solvent separately. An overview of the antioxidant and cytotoxic potential variation in $U$. barbata dry extracts was suggested at the end of this study. 


\section{Results}

2.1. Preparation of Usnea barbata (L.) F.H. Wigg. Dry Extracts and Determination of Metabolites Content

\subsubsection{Lichen Extraction Yield}

$U$. barbata, freshly harvested and dried, had a grey-green color, a fresh smell, and a spicy taste. The obtained value of the loss on drying was $10.94 \pm 0.94 \%$ for the dried lichen.

The dry extracts of $U$. barbata prepared in five different solvents had various colors, depending on the other organic compounds extracted in each solvent. The obtained yields are reported in Table 1.

Table 1. The temperature values for refluxing at Soxhlet, extraction yield, and colors of UBDE using different solvents.

\begin{tabular}{cccc}
\hline UBDE & Temperature of Extraction & Yield (\%) & UBDE Color \\
\hline Acetone extract & $55-60{ }^{\circ} \mathrm{C}$ & 6.36 & Yellow-brown \\
Ethyl acetate extract & $75-80{ }^{\circ} \mathrm{C}$ & 6.27 & Brown-yellow \\
\hline Ethanol extract & $75-80{ }^{\circ} \mathrm{C}$ & 12.52 & Light brown \\
Methanol extract & $65{ }^{\circ} \mathrm{C}$ & 11.29 & Brown \\
\hline Water extract & $95-100^{\circ} \mathrm{C}$ & 1.98 & Dark brown-reddish \\
\hline
\end{tabular}

It can be noted that UBDE in water revealed the lowest yield; the extracts in acetone and ethyl acetate showed approximately three times higher products than in water, and their values are very similar (6.36\% for acetone extract and $6.27 \%$ for ethyl acetate extract). The highest yield was on UBDE in ethanol (12.52\%) and methanol (11.29\%), about two times higher than in both previous solvents. The color and the physical properties of all five UBDE were different, varying from yellow-brown (acetone extract) to dark brown-reddish (water extract) (Table 1).

\subsubsection{UHPLC Determination of the Usnic Acid Content}

The corresponding chromatograms were represented in Figure 1. Other peaks can be recorded in the following chromatograms, corresponding to other metabolites extracted in UBDE in methanol, ethanol, and water. Figure $1 \mathrm{~d}-\mathrm{f}$ shows that the RT values for these organic compounds were lower than RT for usnic acid ( $2 \mathrm{~min}<\mathrm{RT}<3 \mathrm{~min}$ ).

All of these UHPLC determination data are resumed in Table 2, in which the UAC was reported as mg of usnic acid per gram UBDE. The obtained results illustrated in Table 2 showed that usnic acid was quantified in the highest content in UBDE in ethyl acetate $(376.73 \mathrm{mg} / \mathrm{g})$, followed, in decreasing order, by UBDE in acetone $(282.78 \mathrm{mg} / \mathrm{g})$, in methanol $(137.60 \mathrm{mg} / \mathrm{g})$ and ethanol $(127.21 \mathrm{mg} / \mathrm{g})$; UBDE in water does not contain any usnic acid.

This UHPLC-PDA quantitative determination method was validated for the reference substance, usnic acid; it was the subject of another previously published paper [37]. The linearity was verified by the least-squares procedure, on the $125-2500 \mathrm{mg} / \mathrm{g}$ range (sample units), for a value of $R^{2}$ of 0.99988 . The accuracy expressed as percentage relative error is $2.26 \%$. The precision, calculated as repeatability at the concentration $1250 \mathrm{mg} / \mathrm{g}$, and presented as relative standard deviation (RSD), is $1.16 \%$. The limit of quantification (LOQ) was determined at $2.5 \mathrm{mg} / \mathrm{g}$ with a "signal-to-noise" ratio $=14: 1$. The limit of detection (LOD) was $1.25 \mathrm{mg} / \mathrm{g}$. Peak purity index was assessed by spectral reprocessing using Chromera software, on $240-700 \mathrm{~nm}$ range at $15 \%$ of peak height. Visual representation (contour map) of the full spectrum plotted on time was obtained in the same manner on 190-700 nm; moreover, peak identity was confirmed by matching analyte peak spectra and retention times extracted from chromatogram with reference to substance ones. All these data were detailed in the Supplementary Materials. 


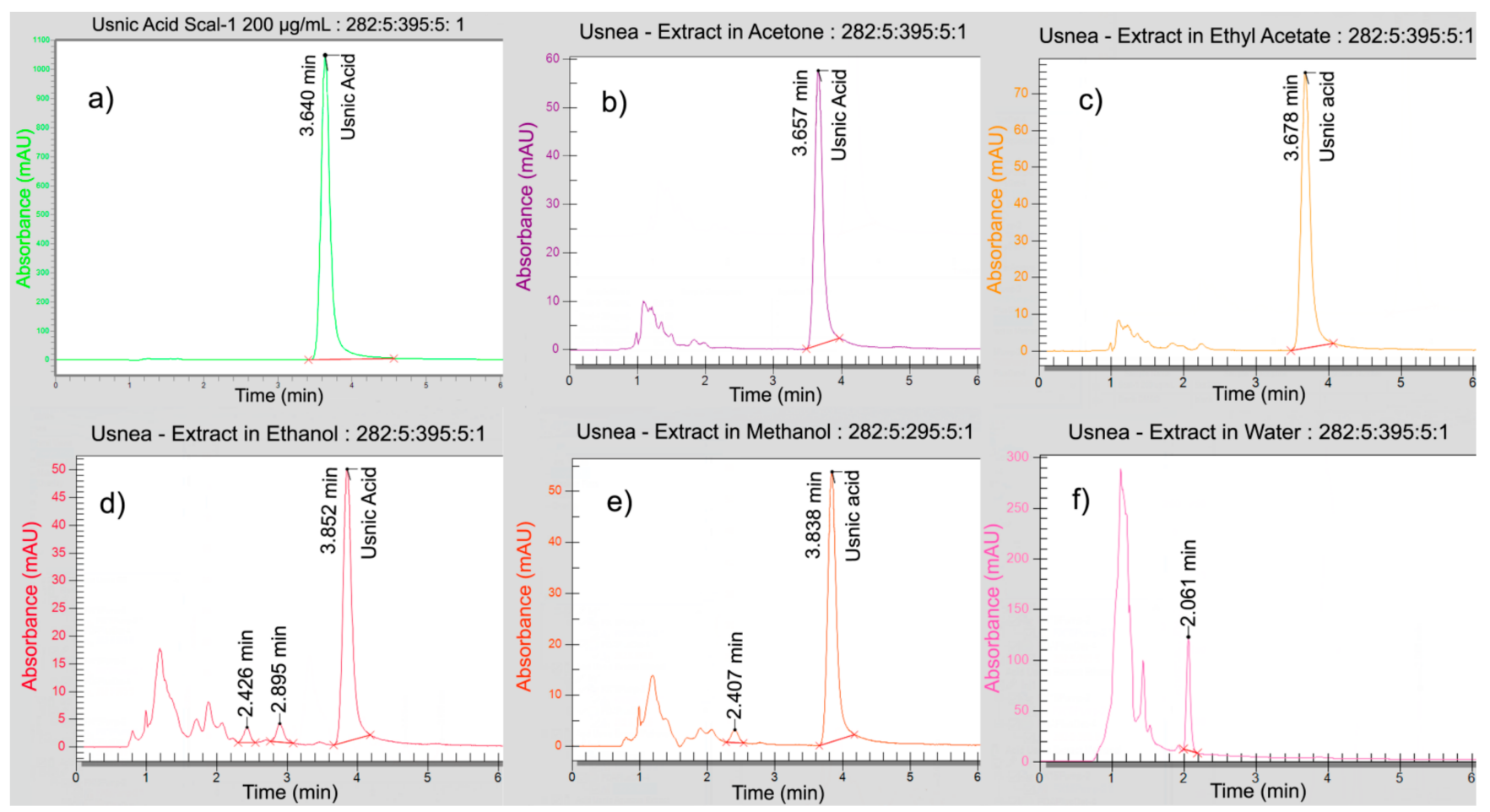

Figure 1. The chromatograms of usnic acid standard (a) and UBDE in different solvents (b-f); the baseline marked lines represent the peak integration.

Table 2. The metabolites content of UBDE in different solvents.

\begin{tabular}{cccc}
\hline UBDE & $\begin{array}{c}\text { UAC } \\
\text { mg/g UBDE }\end{array}$ & $\begin{array}{c}\text { TPC } \pm \text { SD } \\
\text { (mg PyE/g UBDE) }\end{array}$ & $\begin{array}{c}\text { TC } \pm \text { SD } \\
\text { (mg PyE/g UBDE) }\end{array}$ \\
\hline Acetone extract & 282.78 & $101.09 \pm 0.50$ & $24.4 \pm 0.60$ \\
Ethyl acetate extract & 376.73 & $42.40 \pm 1.40$ & $3.85 \pm 0.26$ \\
\hline Ethanol extract & 127.21 & $67.3 \pm 0.50$ & $14.7 \pm 0.05$ \\
Methanol extract & 137.60 & $70.7 \pm 1.70$ & $9.99 \pm 1.70$ \\
\hline Water extract & 0.00 & $45.8 \pm 1.20$ & $1.31 \pm 0.20$ \\
\hline
\end{tabular}

\subsubsection{Determination of the Total Polyphenols Content}

The total polyphenol content is expressed in $\mathrm{mg}$ equivalents of pyrogallol per $\mathrm{g}$ UBDE (mg PyE/g UBDE). The obtained data analysis revealed that UBDE in acetone had the highest TPC: $101.09 \pm 0.5 \mathrm{mg}$ PyE/g UBDE. The lowest TPC values (very closed) were achieved in UBDE in ethyl acetate $(42.40 \pm 1.4 \mathrm{mg}$ PyE/g UBDE) and water (45.8 $\pm 1.2 \mathrm{mg}$ PyE/g UBDE). The UBDE in both alcohols showed similar TPC values: $67.3 \pm 0.5 \mathrm{mg}$ PyE/g UBDE in ethanol and $70.7 \pm 1.7 \mathrm{mg}$ PyE/g UBDE in methanol.

The data obtained in TPC determination were registered in Table 2.

\subsubsection{Determination of the Tannins Content}

The highest content in TC was found in UBDE in acetone $(24.4 \pm 0.6 \mathrm{mg} \mathrm{PyE} / \mathrm{g}$ UBDE), followed, in decreasing order, by UBDE in ethanol (14.7 $\pm 0.05 \mathrm{mg}$ PyE/g UBDE), in methanol (9.99 $\pm 1.7 \mathrm{mg}$ PyE/g UBDE) and ethyl acetate (3.85 $\pm 0.26 \mathrm{mg} \mathrm{PyE} / \mathrm{g} \mathrm{UBDE})$. UBDE in water revealed the lowest TC value (1.31 $\pm 0.2 \mathrm{mg}$ PyE/g UBDE), as seen from Table 2. Based on the data from Table 2, Figure 2 could offer a relevant comparative image of the content of the secondary metabolites in all U. barbata dry extracts. 


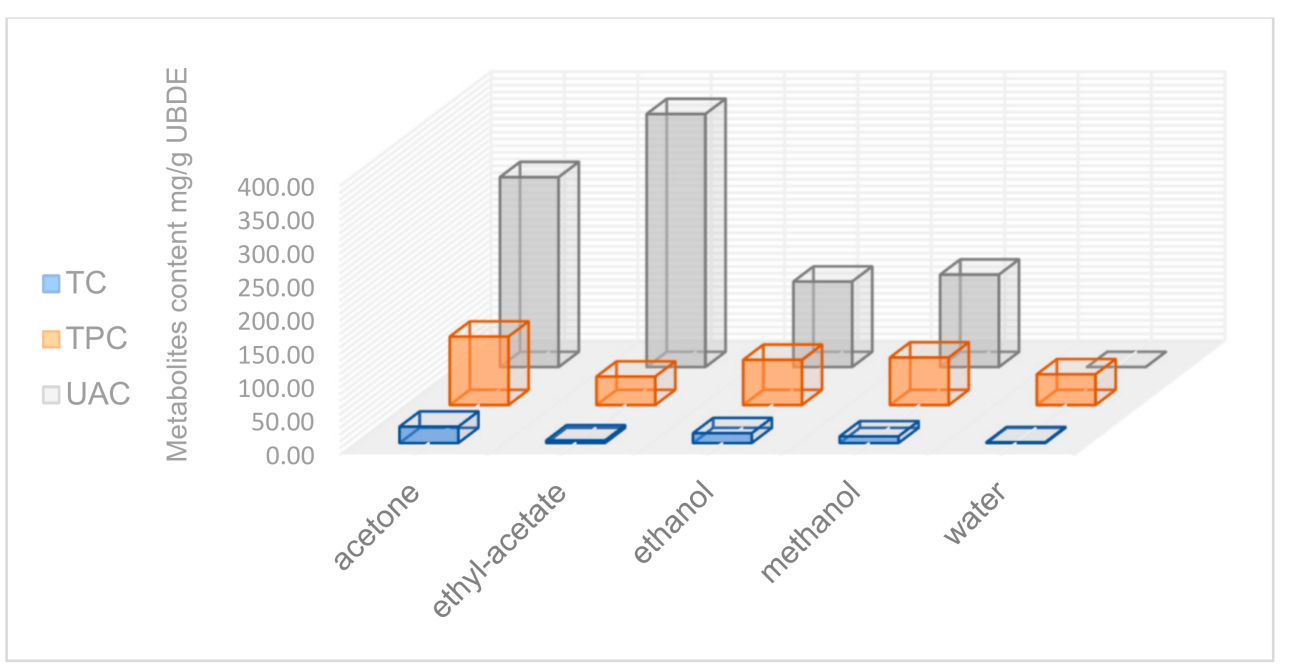

Figure 2. The secondary metabolite content (UAC, TPC, and TC) in UBDE in different solvents.

\subsubsection{Determination of the Total Polysaccharides Content}

From $50.173 \mathrm{~g}$ dried lichen, $2.704 \mathrm{~g}$ polysaccharides were obtained; subtracting the value of the loss on drying of lichen, the yield of this process was $5.39 \%$.

\subsection{Evaluation of the Antioxidant Activity}

The obtained results analysis could note that UBDE in methanol had the highest antioxidant activity (DPPH IC $\mathrm{I}_{50}=3300 \mu \mathrm{g} / \mathrm{mL}$ ). The following UBDE, in ethanol and acetone, had very similar values of DPPH IC $50(4462 \mu \mathrm{g} / \mathrm{mL}$ and, respectively, $4608 \mu \mathrm{g} / \mathrm{mL})$. UBDE in water had DPPH IC $50=6211 \mu \mathrm{g} / \mathrm{mL}$, the lowest antioxidant activity was registered by UBDE in ethyl acetate, with DPPH IC $50=7701 \mu \mathrm{g} / \mathrm{mL}$ (Table 3).

Table 3. DPPH $\mathrm{IC}_{50}$ values for tested UBDE.

\begin{tabular}{cccccc}
\hline UBDE & $\begin{array}{c}\text { Acetone } \\
\text { Extract }\end{array}$ & $\begin{array}{c}\text { Ethyl Acetate } \\
\text { Extract }\end{array}$ & $\begin{array}{c}\text { Ethanol } \\
\text { Extract }\end{array}$ & $\begin{array}{c}\text { Methanol } \\
\text { Extract }\end{array}$ & $\begin{array}{c}\text { Water } \\
\text { Extract }\end{array}$ \\
\hline $\mathrm{DPPH} \mathrm{IC50}(\mu \mathrm{g} / \mathrm{mL})$ & 4608 & 7701 & 4462 & 3300 & 6211 \\
\hline
\end{tabular}

Each type of UBDE has revealed a directly proportional relationship between the concentration of the extracts and their antioxidant activity.

The correlation between TPC and AA expressed by \% scavenger DPPH could be evaluated by linear trendlines, correlation coefficients $\left(R^{2}\right)$, and linear equations for each tested extract. The $R^{2}$ values showed a high correlation for UBDE in methanol $\left(R^{2}=0.9453\right)$ and ethanol $\left(R^{2}=0.9308\right)$, a moderate correlation for UBDE in water $\left(R^{2}=0.7250\right)$ and acetone $\left(R^{2}=0.7051\right)$, and a low correlation for UBDE in ethyl acetate $\left(R^{2}=0.5408\right)$.

The same model could evaluate the correlation between TC and AA; the linear equations and $R^{2}$ values are registered in Table 4 .

Table 4. The correlation between TCP and TC values and AA (\% scavenger DPPH) for each UBDE.

\begin{tabular}{|c|c|c|c|c|c|c|}
\hline Parameter & UBDE & Acetone Extract & Ethyl acetate Extract & Ethanol Extract & Methanol Extract & Water Extract \\
\hline \multirow{2}{*}{ TPC } & $\begin{array}{c}\text { Linear } \\
\text { equation }\end{array}$ & $y=0.0527 x+5.189$ & $y=0.0873 x+0.9336$ & $y=0.0988 x+5.2527$ & $y=0.104 x+3.5547$ & $\mathrm{y}=0.0861 \mathrm{x}+4.0976$ \\
\hline & $\mathrm{R}^{2}$ value & 0.7051 & 0.5408 & 0.9308 & 0.9453 & 0.725 \\
\hline \multirow{2}{*}{$\mathrm{TC}$} & Linear & $y=0.22 x+5.1893$ & $y=0.9576 x+3.9446$ & $y=0.4525 x+5.2502$ & $y=0.7356 x+3.5564$ & $y=2.9895 x+4.1226$ \\
\hline & $\mathrm{R}^{2}$ value & 0.705 & 0.5383 & 0.9309 & 0.9452 & 0.7221 \\
\hline
\end{tabular}


The correlations between UAC, TPC, TC (mg/g UBDE), and AA (expressed by DPPH $\mathrm{IC}_{50} \mathrm{mg} / \mathrm{mL}$ ) of all UBDE were investigated by using regression analysis (Figure $3 \mathrm{a}-\mathrm{c}$ ).

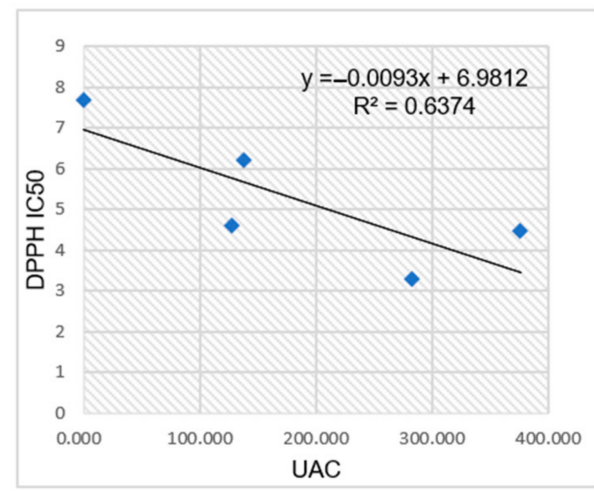

(a)



(b)

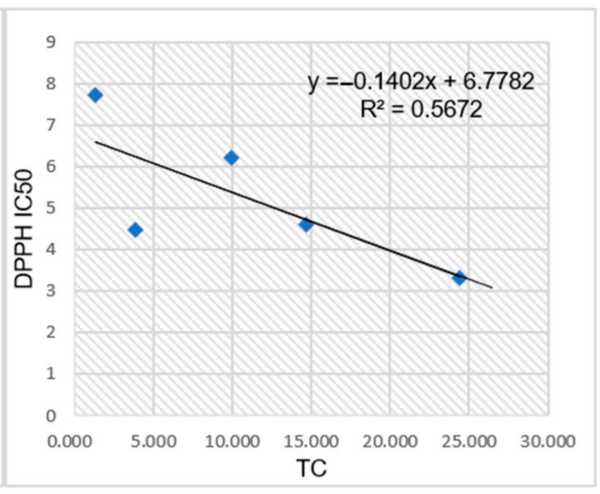

(c)

Figure 3. The correlation between UAC (a), TPC (b), TC (c), and AA (expressed by DPPH IC ${ }_{50}$ ) of UBDE.

Analyzing the linear trendlines, linear equations, and regression coefficients $\mathrm{R}^{2}$ reported in Figure 3 it could be noted that there exists a moderate correlation between DPPH $\mathrm{IC}_{50}$ and UAC $\left(\mathrm{R}^{2}=0.6374\right)$ and TC $\left(\mathrm{R}^{2}=0.5672\right)$ and a low correlation between DPPH $\mathrm{IC}_{50}$ and TPC $\left(\mathrm{R}^{2}=0.3525\right)$.

The antioxidant activity of the tested UBDE (expressed by DPPH IC $\mathrm{I}_{50}$ ) in correlation with their phytochemical profile was shown in Figure 4a.

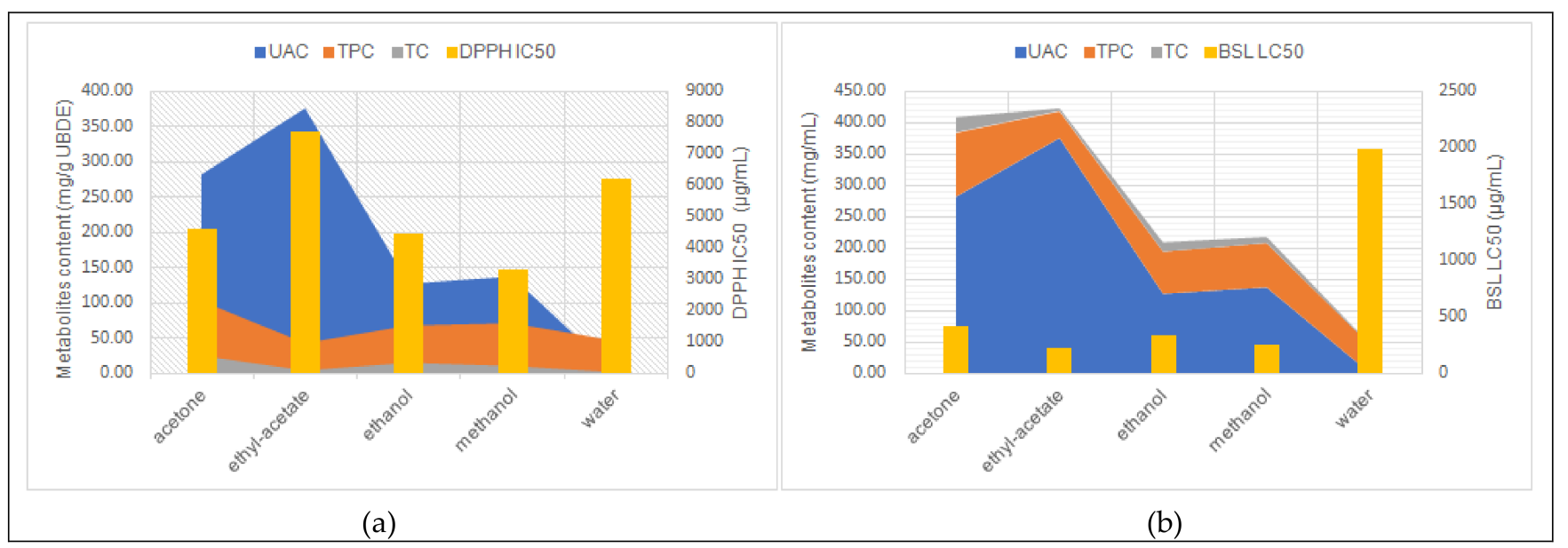

Figure 4. The correlation between the phytochemical profile of UBDE and antioxidant activity (a) and cytotoxic effect (b), expressed by DPPH IC 50 and BSL $\mathrm{LC}_{50}$, respectively.

Figure $4 \mathrm{~b}$ highlights the correlation between the phytochemical profile of UBDE and their cytotoxic activityIt can be seen that the cytotoxicity of UBDE varies directly proportional to the content of secondary metabolites. Thus, UBDE in ethyl acetate and acetone, with the greatest UAC, have the highest levels of cytotoxicity (Figure $4 \mathrm{~b}$ ) and, at the same time, a low antioxidant effect (Figure 4a).

\subsection{Evaluation of the Cytotoxic Activity by Brine Shrimp Lethality Assay}

Six stock solutions in DMSO $(\mathrm{mg} / \mathrm{mL})$ of usnic acid and UBDE were obtained; three different usnic acid and UBDE dilutions in DMSO 0.1\% were tested (Table 5). All the UBDE and usnic acid reported cytotoxic effects directly proportional to the concentrations of the tested solutions. 
Table 5. The BSL assay protocols and larval mortality (\%) mean values \pm SD for an experimental four repetitions.

\begin{tabular}{|c|c|c|c|c|c|c|c|c|}
\hline \multirow{2}{*}{$\begin{array}{c}\text { Stock } \\
\text { Solutions } \\
(\mathrm{mg} / \mathrm{mL})\end{array}$} & \multirow{2}{*}{$\begin{array}{c}\text { Usnic Acid } \\
12.9\end{array}$} & \multirow{2}{*}{$\begin{array}{c}\text { UBDE in } \\
\text { Acetone } \\
17.2\end{array}$} & \multirow{2}{*}{$\begin{array}{c}\begin{array}{c}\text { UBDE in } \\
\text { Ethyl acetate }\end{array} \\
16.2\end{array}$} & \multirow{2}{*}{$\begin{array}{c}\text { UBDE } \\
\text { in Ethanol } \\
16.1\end{array}$} & \multirow{2}{*}{$\begin{array}{c}\text { UBDE in } \\
\text { Methanol } \\
16.1\end{array}$} & \multicolumn{2}{|c|}{$\begin{array}{l}\text { UBDE in } \\
\text { Water }\end{array}$} & \multirow{2}{*}{$\begin{array}{c}\begin{array}{c}\text { Water/DMSO } \\
(\mathbf{0 . 1} \%)\end{array} \\
\begin{array}{c}\text { Control } \\
\text { Samples }\end{array} \\
\end{array}$} \\
\hline & & & & & & $16.0^{\text {dil }}$ & $16.0 *$ & \\
\hline Tested samples & \multicolumn{8}{|c|}{ Concentrations $(\mu \mathrm{g} / \mathrm{mL})$} \\
\hline $1: 50$ & 24.8 & 34.4 & 32.4 & 32.2 & 32.2 & 32 & 320 & - \\
\hline $1: 10$ & 160 & 172 & 162 & 161 & 161 & 160 & 1600 & - \\
\hline $1: 3.4$ & 387 & 516 & 486 & 483 & 483 & 480 & 4800 & - \\
\hline \multicolumn{9}{|c|}{ Mortality (\%) } \\
\hline $1: 50$ & $8.96 \pm 7.60$ & $14.94 \pm 1.55$ & 0.00 & $15.28 \pm 3.69$ & $23.51 \pm 11.43$ & 0 & 0 & 0 \\
\hline $1: 10$ & $20.95 \pm 6.32$ & $38.82 \pm 12.6$ & $33.53 \pm 14.7$ & $29.37 \pm 13.1$ & $24.02 \pm 3.35$ & 0 & $50 \pm 5.77$ & 0 \\
\hline 1:3.4 & $40.07 \pm 17.8$ & $54.24 \pm 16.9$ & $100 \pm 0$ & $75.54 \pm 28.2$ & $87.82 \pm 15.8$ & 0 & $100 \pm 0$ & 0 \\
\hline
\end{tabular}

dil UBDE in water samples 1:50; 1:10; 1:3.4; ${ }^{*}$ Additionally UBDE in water samples with 1:5; 1:1; 1:0.3 dilutions.

Evaluation of the cytotoxicity of the UBDE showed the appearance of effects for all extracts, except for UBDE in ethyl acetate $(32.4 \mu \mathrm{g} / \mathrm{mL})$ and UBDE in water $(32,160,480$, $320 \mu \mathrm{g} / \mathrm{mL}$ ) (Table 5). At concentrations above $100 \mu \mathrm{g} / \mathrm{mL}$ (1:10), the recorded effects indicate low toxicity (mortality between $20 \%$ and $38 \%$ ).

The brine shrimp larvae were exposed to concentrations over $300 \mu \mathrm{g} / \mathrm{mL}$; they were affected by the content of the tested extract, and the registered mortality was significant, except UBDE in water (Table 5).

Comparing the results between the effects induced by UBDE in different solvents and the usnic acid, reported to the negative control (water) by Dunnett test, the statistical analysis showed significant differences $(p$-value $<0.05$ ) in the case of exposed lots (Table 6). The mortalities were statistically significantly different between negative control samples and treated groups. The diversity of interactions induced by the composition of the extracts that possibly influence the statistical response significance, below the statistical significance level, is the 1:10 fold dilution group (Table 6).

Table 6. The analysis of variance (one way) for all tested samples; the analyzed groups were exposed to different concentrations.

\begin{tabular}{cccccccc}
\hline \multicolumn{7}{c}{ ANOVA } \\
\hline $\begin{array}{l}\text { Source of } \\
\text { Variation }\end{array}$ & d.f. & SS & MS & F & $p$-Value & F Crit & Omega Sqr. \\
\hline $1: 50$ & 6 & 2113.23 & 352.20 & 5.59 & 0.013 & 3.81 & 0.50 \\
$1: 10$ & 6 & 5932.10 & 988.68 & 1.76 & 0.16 & 3.81 & 0.14 \\
$1: 3.4$ & 6 & $32,172.06$ & 5362.01 & 22.70 & 0.00000004 & 3.81 & 0.82 \\
\hline
\end{tabular}

Analyzing the data registered in Table 6; Table 7, through the Meyer [38] and Clarkson's [39] toxicity index it could be mentioned that UBDE in water had non-cytotoxic activity $\left(\right.$ BSL LC $\left._{50}=1983.68 \mu \mathrm{g} / \mathrm{mL}\right)$, followed, in increasing order, by usnic acid $\left(B S L \mathrm{LC}_{50}=\right.$ $424.75 \mu \mathrm{g} / \mathrm{mL}$ ) and acetone (BSL LC $50=411.77 \mu \mathrm{g} / \mathrm{mL})$, ethanol $\left(\right.$ BSL LC $_{50}=338.39 \mu \mathrm{g} / \mathrm{mL}$ ) and methanol (BSL LC $50=250.19 \mu \mathrm{g} / \mathrm{mL}$ ). The highest cytotoxic activity was recorded by ethyl acetate extract (BSL LC $50=219.59 \mu \mathrm{g} / \mathrm{mL}$ ) (Table 7). All the results obtained in this analysis were calculated using the Probit method, and the lethality ( $\mathrm{LC}_{50}$ and $\mathrm{LC}_{100}$ and $95 \%$ interval confidence) was registered in Table 7. 
Table 7. The BSL assay results $\left(\mathrm{LC}_{50}\right.$ and $\left.\mathrm{LC}_{100}\right)$ and toxicity evaluation of usnic acid and UBDE tested in $24 \mathrm{~h}$ exposure.

\begin{tabular}{|c|c|c|c|c|c|}
\hline \multirow{2}{*}{ Samples } & \multirow{2}{*}{$\begin{array}{c}\mathrm{LC}_{50} \\
(\mu \mathrm{g} / \mathrm{mL})\end{array}$} & \multicolumn{2}{|c|}{ Confidence Interval 95\% } & \multirow{2}{*}{$\begin{array}{c}\mathrm{LC}_{100} \\
(\mu \mathrm{g} / \mathrm{mL})\end{array}$} & \multirow{2}{*}{$\begin{array}{l}\text { Toxicity } \\
\text { Index * }\end{array}$} \\
\hline & & Lower & Upper & & \\
\hline Usnic acid & 424.75 & 342.20 & 507.31 & 923.42 & highly toxic \\
\hline UBDE in acetone & 411.77 & 274.26 & 549.29 & 1103.41 & highly toxic \\
\hline UBDE in ethyl acetate & 219.59 & 176.09 & 263.09 & 359.70 & highly toxic \\
\hline UBDE in ethanol & 338.39 & 265.02 & 411.74 & 808.53 & highly toxic \\
\hline UBDE in methanol & 250.19 & 182.91 & 318.28 & 593.78 & highly toxic \\
\hline UBDE in water & 1983.68 & 1455.84 & 2511.52 & 3428.64 & non-toxic \\
\hline
\end{tabular}

* Toxicity index: $\mathrm{LC}_{50}>1000 \mu \mathrm{g} / \mathrm{mL}$ non-toxic, between $500-1000 \mu \mathrm{g} / \mathrm{mL}$ low or moderate toxic and $100-500 \mu \mathrm{g} / \mathrm{mL}$ highly toxic.

Microscopic observations showed general morphological changes (Figure 5), such as body deformation (Figure $5 \mathrm{c}-\mathrm{e}$ ) and shedding disturbance (Figure $5 \mathrm{c}, \mathrm{d}$ ). Inhibition of larval development was also observed compared to unexposed organisms (Figure 5a). Evident at the cellular level is the accumulation of cytoplasmic inclusions and the loss of intercellular connections. These cytological phenomena are significant in UBDE in methanol, ethyl acetate, and acetone (Figure $5 \mathrm{c}-\mathrm{e}$ ).
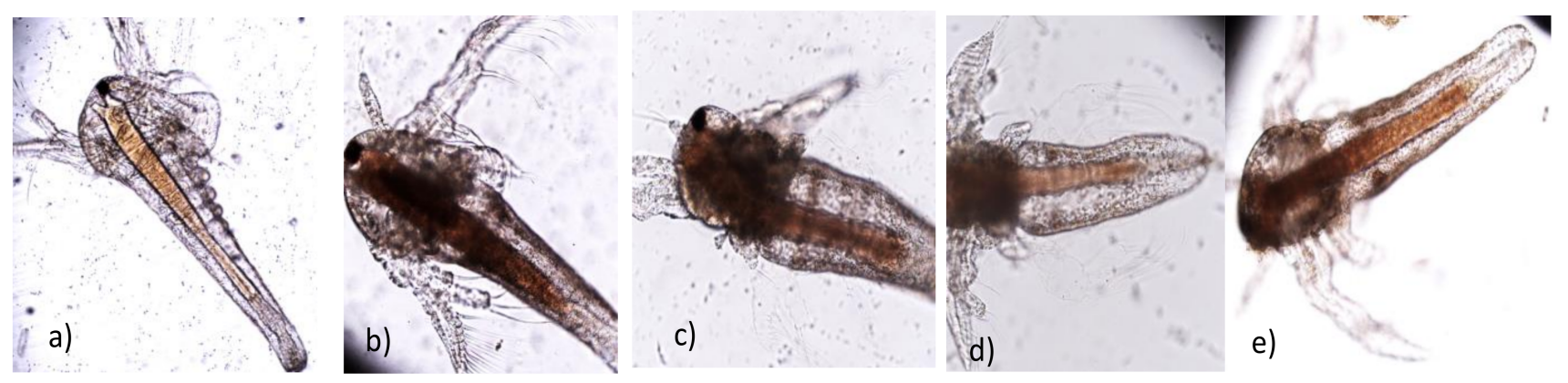

Figure 5. Microscopic details of exposed larvae-(a) negative control; (b) UBDE in water; (c) UBDE in methanol; (d) UBDE in ethyl acetate; (e) UBDE in acetone (magnification $\times 100)$.

\section{Discussion}

The secondary metabolites and the lichen biological activities are influenced by environmental factors such as seasonal variation, temperature, light, and habitat. The correlation between the lichen habitat and their usnic acid content was shown by Cansaran et al. (2008); the lichens have the highest usnic acid content at the altitudes between 700 and $1500 \mathrm{~m}$ because the water remains liquid - the probability of water remaining as ice is higher above this elevation [40]. Loss on drying was calculated for the lichen sample to know the accurate weight of dried lichen, subtracting loss on drying value from the weighed mass.

For obtaining $U$. barbata extracts, the following five solvents: acetone, ethyl acetate, ethanol, methanol, and water, were used. They are most frequently used for the preparation of plant extracts, solubilizing most phytoconstituents. Determining TPC and AA of various plant extracts in water, ethanol, and acetone, Dirar et al. (2019) [41] (p. 263) provided that acetone extracts had the highest TPC for the numerous studied species. Comparing the ethanol and methanol plant extracts, Sultana et al. (2009) [42] showed that methanol extracts had the highest TPC. In our study, TPC values decreased in order: UBDE acetone, methanol, and ethanol. Polysaccharides are, generally, soluble in water [43]; the solubility of usnic acid increases in order: water, ethanol, methanol, acetone, and ethyl acetate [44]. Refluxing at Soxhlet $8 \mathrm{~h}$, followed by filtration and concentration of the obtained extract, represent one of the most efficient extraction methods. From $400 \mathrm{~g}$ of $U$. longissima dried lichen, Maulidiyah et al. (2011) [45] obtained $28.79 \mathrm{~g}$ dry acetone extract; the yield of the extract was slightly higher $(7.19 \%)$ than that obtained in our present study $(6.36 \%)$. 
The total polyphenol content was determined in various extracts of Usnea sp.: U. florida (methanol extract: $10.5 \mathrm{mg} / \mathrm{g}$, water extract: $10.4 \mathrm{mg} / \mathrm{g}$ ); U. gattensis (acetone extract: $14 \mathrm{mg} / \mathrm{g}$, methanol extract: $35 \mathrm{mg} / \mathrm{g}$ ); U. longissima (methanol extract: $38.6 \mathrm{mg} / \mathrm{g}$, water extract: $18.3 \mathrm{mg} / \mathrm{g}$ ) [46].

The variable content of usnic acid in various $U$. barbata extracts depended on the used solvents and extraction methods. Zugic et al. (2016) analyzed the usnic acid content in four $U$. barbata different extracts: supercritical $\mathrm{CO}_{2}$ extract, Soxhlet extracts (ether and ethanol fractions), and 70\% ethanol macerate; the obtained values decreased in order: $81.41 \%$ usnic acid in supercritical $\mathrm{CO}_{2}$ extract, $67.09 \%$ in ether fraction, $2.43 \%$ in ethanol fraction and $1.39 \%$ in $70 \%$ ethanol macerate [47].

Analyzing the obtained results of the antioxidant activity, we could observe that UBDE in methanol and ethanol presented a higher AA than UBDE in acetone even if their TPC was lower than in it. This result can be due to the polyphenols soluble in alcohols with a higher antioxidant effect than other specific phenolic compounds extracted in acetone. In their study, Dirar et al. (2019) [41] (pp. 263-265), describing similar results, stated that phenolic compounds with free hydroxyl groups have intense free radical scavenging activities. The high correlation between TPC and AA available in UBDE in methanol and ethanol could be explained similarly. The water extract contains polyphenols and polysaccharides [48], and both classes of organic compounds [49] have antioxidant activity [50]; UBDE in ethyl acetate, which also had the lowest TPC, reported the lowest AA. It is essential to report the high correlation between AA of all UBDE (\% scavenger DPPH) and their TPC (Table 4).

In their studies on $U$. barbata acetone extract, Rancovic et al. (2012) [51] found a TPC value of $31.3 \mu \mathrm{g} / \mathrm{mL}, \mathrm{DPPH} \mathrm{IC}_{50}=667.9 \mu \mathrm{g} / \mathrm{mL}$, and a high correlation between TPC and AA. In the scientific literature, numerous studies evaluate the antioxidant potential of lichens from various Earth zones by different methods [52]. It has been shown that the lichen extracts in different solvents and their isolated metabolites have an antioxidant activity [53]. The BSL assay cannot determine the mechanism of action of the metabolites from the tested $U$. barbata extracts; it can only provide a preliminary screening that can be followed by more specific bioassays. Lethality and cytological changes in brine shrimp larvae are easy to assess in these organisms [54], making screening very fast and efficient. A study on liver cells [55] showed an increase in lipid droplet content and fragmentation of the endoplasmic reticulum in conditions of exposure to usnic acid. We consider these cytological aspects similar to those observed in the organisms exposed in UBDE (Figure 5b-e).

Many researchers evaluated the biological potential of the lichen extracts and isolated constituents; also, usnic acid is recognized as the most specific and bioactive lichen secondary metabolite. Synthesizing the obtained results, the influence of UAC from UBDE on the studied biological activities could be analyzed. Significantly, UBDE in ethyl acetate, which has the highest UAC, has the lowest antioxidant effect, and also the highest cytotoxicity. Numerous studies highlighted both biological effects of the various lichen extracts and usnic acid. Generally, the antioxidant capacity and cytotoxicity are considered opposite activities concerning living cells. Thus, it could be expected that a compound (or plant extract) with a high antioxidant effect to achieve high cellular protection and to have low cytotoxic action. It was observed that the $U$. barbata dry extracts with high cytotoxic effects show reduced levels of antioxidant activity.

Analyzing the studied UBDE, it can be observed that the five solvents selected for extraction are frequently used in medical and pharmaceutical research laboratories. In the Pfizer solvent selection guide (according to the Green Chemistry concept) [56] (pp. 3-6), these solvents are included in the "preferable" category, with the lowest toxicity and the highest safety. Acetone, ethanol and methanol are miscible with water; only ethyl acetate has shown a low solubility in water [56] (p. 4). This study suggests acetone, ethyl acetate, ethanol, and methanol as suitable solvents for $U$. barbata extracts, indicating the proving arguments. Thus, both alcohols provided the highest extraction yields of UBDE; this advantage is accompanied by a wide range of biologically active compounds. The 
extraction yields in acetone and ethyl acetate are about two times lower; however, both UBDE have a significant UAC because usnic acid presents optimal solubility in these two solvents. U. barbata dry acetone extract has a substantial UAC. It also contains other secondary metabolites with various biological effects. Instead, if the main objective is to obtain UBDE with the highest content of usnic acid, ethyl acetate would be the most appropriate solvent.

\section{Materials and Methods}

\subsection{Lichen Extraction Yield}

For the present studies, $U$. barbata was harvested from a region located at $900 \mathrm{~m}$ altitude from the Călimani mountains (Suceava county, Romania) in March 2020 because the lichen secondary metabolites are at maximum level [57] in early winter or early spring and a minimum level during the summer [58].

$U$. barbata was manually harvested directly from the branches of conifers. The fresh lichen was cleaned of impurities and dried at $18-25^{\circ} \mathrm{C}$, in a herbal room, sheltered from the sun rays. After drying, the obtained herbal product was preserved for a long time in the same conditions for use in subsequent studies. The lichen species identification was performed by the Department of Pharmaceutical Botany of the Faculty of Pharmacy, Ovidius University of Constanta, using standard methods.

A weighing ampoule brought to constant weighed together with the lichen sample was kept in the oven at $105{ }^{\circ} \mathrm{C}$, for two hours, and then cooled in the desiccator and weighed. The drying process continued in the oven for one hour, followed by cooling and weighing, until the constant weight was achieved [59].

The dried lichen was ground to a powder and extracted for eight hours with each solvent (acetone, ethyl acetate, ethanol, methanol, water) in a Soxhlet continuous reflux system. Extraction was different for each extract, being around the boiling point of each solvent. After filtration, the water extract was concentrated on rotavapor Butchi R-215 with a vacuum controller V-850 lyophilized a with freeze-dryer Christ Alpha 1-2 B Braun Biotech International with vacuum pump RZ 2.5.

In the other four $U$. barbata extracts, the rotary evaporator TURBOVAP 500 Caliper was used for evaporation of the solvents. Next, these extracts were kept for $16 \mathrm{~h}$ in a chemical exhaust hood for each optimal solvent evaporation.

The obtained dry extracts were transferred to sealed-glass bottles and stored in the freezer (Sirge FREEZER) at $-24^{\circ} \mathrm{C}$ until processing.

\subsection{UHPLC Determination of the Usnic Acid Content}

Usnic acid was separated in UBDE dissolved in DMSO following a chromatographic column filled with reverse stationary phase type C18. After elution from the column, the compounds were analyzed using the Photodiode Array (PDA) Detector; the signal corresponding to the target compound was recorded at a wavelength of $282 \mathrm{~nm}$ [37].

The PerkinElmer ${ }^{\circledR}$ Flexar $^{\circledR}$ FX-15 UHPLC system fitted with a Flexar FX PDA-Plus photodiode array detector was the platform for this analysis (UHPLC-PDA). The Brownlee Analytical C18 column is filled with $5 \mu \mathrm{m}$ superficially porous particles; it has an inner diameter of $4.6 \mathrm{~mm}$ and a length of $150 \mathrm{~mm}$ [60].

Working conditions consisted of: flow $=1.5 \mathrm{~mL} / \mathrm{min}$; temperature in the column compartment $=25^{\circ} \mathrm{C}$; injection volume $=20 \mu \mathrm{L}$; analysis time: $10 \mathrm{~min}$. The mobile phase was an isocratic system methanol/water/glacial acetic acid (80:15:5). The samples were UBDE dissolved in acetone, ethyl acetate, ethanol, methanol, and water and diluted to 1:50 with DMSO. The standard-stock solution was prepared by dissolving $20 \mathrm{mg}$ of usnic acid (Sigma-Aldrich, St. Louis, MO, USA) in $10 \mathrm{~mL}$ DMSO.

The standard solutions (Scal) were prepared from the standard-stock solution; the following concentrations were obtained: $10,20,50,100$, and $200 \mu \mathrm{g} / \mathrm{mL}$, with which the calibration curve was drawn: $\left(y=\left(48.46290 \times 10^{3}\right) x+\left(-40.16791 \times 10^{3}\right) ; R^{2}=0.99988\right)$ (Figure 6). 


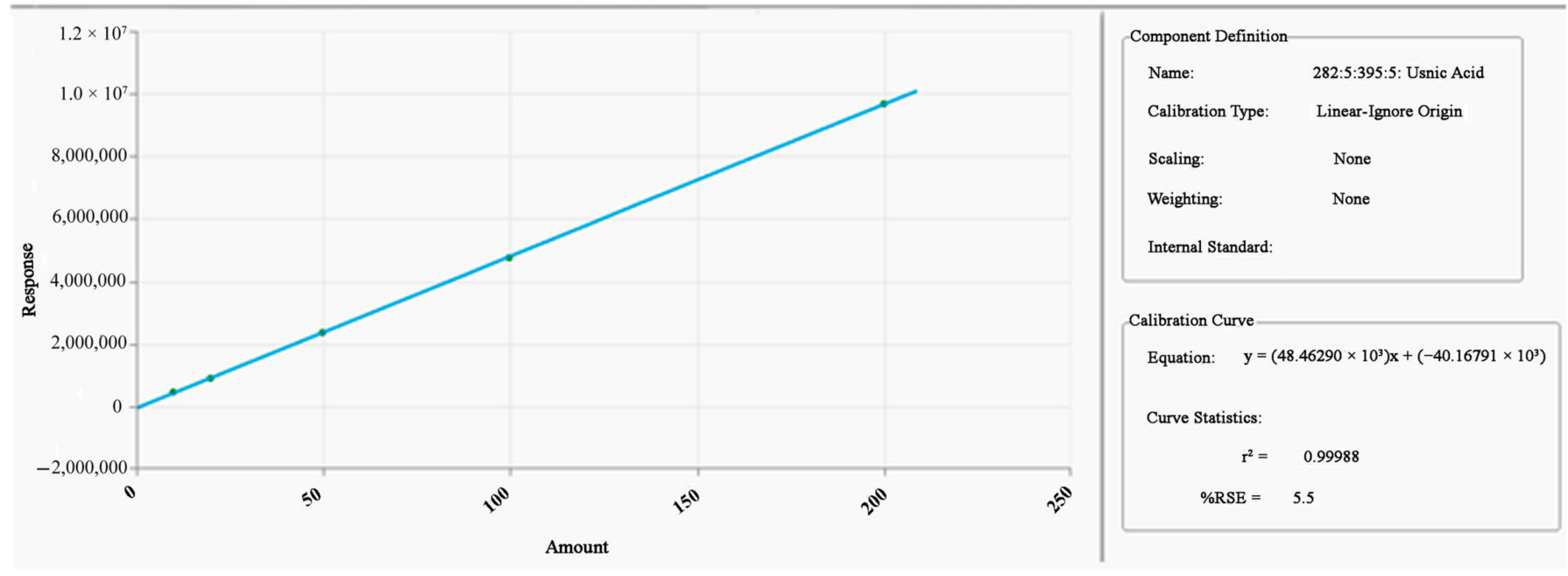

Figure 6. The calibration curve of usnic acid.

The Quality Control (QC) solutions were prepared by adding $20 \mu \mathrm{g}$ standard-stock solution in a volumetric flask of $10 \mathrm{~mL}$ and completing with DMSO up to the mark.

Two samples of QC solutions of $40 \mu \mathrm{g} / \mathrm{mL}$ were injected at the beginning and at the end of the sequence to assure the accuracy of the analysis. Accuracy between 97.7-98.8 indicates that the analysis is highly accurate.

The conversion of the standard solution concentration into the sample concentration was calculated using the formula:

$$
\mathrm{C}_{\text {smpl.UA }}=\mathrm{C}_{\text {std.UA }} / 1000 * \mathrm{D} / 5 * 100
$$

where: $C_{\text {smpl.UA }}$ is the usnic acid concentration of the sample; $C_{\text {std.UA }}$ is the usnic acid concentration of Standard Solution; D is the sample dilution factor-according to this procedure, $\mathrm{D}$ value $=50$. The verification of the method accuracy was realized by comparing the QC standard theoretical concentration with the concentration obtained from its analysis. This formula was used to calculate the accuracy of the method:

$$
\mathrm{AQC} \%=\mathrm{CcQC} / \mathrm{CTQC} * 100
$$

$\mathrm{AQC} \%$ is the accuracy of determining the QC solution; CcQC is the concentration of the injected QC solution; CTQC is the theoretical concentration of the QC solution. The chromatogram of standard solution $200 \mu \mathrm{g} / \mathrm{mL}$ (Scal-1) shows that the usnic acid retention time (RT) was about $3.640 \mathrm{~min}$ (Section 2.1.2, Figure 1).

All the results were obtained using PerkinElmer Chromera Manager Software, on HP ProDesk 400 G1 MT Intel ${ }^{\circledR}$ Core $^{\mathrm{TM}}$ i5-4570 PC.

\subsection{Determination of the Total Polyphenols Content}

The total polyphenols content was determined with Folin-Ciocâlteu reagent (phosphomolybdotungstic acid) using a method provided by Maisetta et al. [61] Pyrogallol was used as standard, and the TPC values were calculated as mg of Pyrogallol equivalents (PyE) per $g$ UBDE.

For this analysis, to five volumetric flasks of $25 \mathrm{~mL}, 5 \mathrm{~mL}$ of each UBDE (A1-A5) was added, filtered through 99 filter paper. They were completed up to the sign with the same solvent, and B1-B5 solutions were obtained. In five volumetric flasks of $25 \mathrm{~mL}, 2 \mathrm{~mL}$ of each solution B1-B5 were added, with $1 \mathrm{~mL}$ of Folin-Ciocâlteu reagent, $10 \mathrm{~mL}$ water, and $290 \mathrm{~g} / \mathrm{L}$ of $\mathrm{Na}_{2} \mathrm{CO}_{3}$ solution, up to the mark; a blue coloration resulted in each volumetric flask. After $30 \mathrm{~min}$ of reaction at room temperature [62], the absorbencies (each value was noted with A1 in the calculation formula) were determined at $760 \mathrm{~nm}$, using a Jasco V630 UV-Vis Spectrophotometer (Japan) with Spectra Manager ${ }^{\mathrm{TM}}$ Software. 
All the determinations were run in triplicate; using the Microsoft Excel software (Microsoft Corporation, Redmond, WA, USA), the standard deviations (SD) and the mean values were calculated.

\subsection{Determination of the Tannins Content}

According to a previous study reported by Galvao et al. (2018) [63], the tannins content was determined. The procedure consists of three phases: determination of TPC in different UBDE extracts by Folin-Ciocâlteu method (Section 4.3.) absorption of tannins on standardized hide-powder, and determination of the phenolic compounds in the solution remaining after the second phase. The quantification of the molybdenum oxides blue coloration intensity was determined by spectrophotometry $(760 \mathrm{~nm})$. The difference between both determinations even represents the tannin content. All the determinations were performed in triplicate; the data were reported as means $\pm \mathrm{SD}$ using the Microsoft Excel software (Microsoft Corporation, Redmond, WA, USA).

\subsection{Determination of the Polysaccharides Content}

Total polysaccharides were extracted using a classical gravimetric method with ethanol precipitation described in a recent study by Tikhomirova et al. (2020) [64] Approximately $50 \mathrm{~g}$ of dried, chopped lichen was refluxed for $30 \mathrm{~min}$ with $500 \mathrm{~mL}$ of distilled water. The extract was filtered by filter paper in a $250 \mathrm{~mL}$ volumetric flask and completed with water up to the mark. The entire volume of aqueous extract was added in a thin stream on $2000 \mathrm{~mL}$ of $96 \%$ ethanol under continuous stirring. The obtained mucilage precipitate was separated from the liquid phase by filtration through filter paper; then, it was dried in the oven at $105^{\circ} \mathrm{C}$ for $3 \mathrm{~h}$, until constant weight. It was kept in the desiccator until it cooled to room temperature, and then it was weighed.

\subsection{Evaluation of the Antioxidant Activity}

The antioxidant activity was determined on a Jasco V630 UV-Vis Spectrophotometer (Japan) using a DPPH free radical scavenging assay [65].

The DPPH solution was prepared by dissolution of DPPH (Sigma Aldrich) in methanol to obtain an absorbance value of $0.8 \pm 0.02 ; 0.1$ of each UBDE was vortexed with $3.9 \mathrm{~mL}$ of DPPH solution for $30 \mathrm{~s}$. The reaction time at room temperature was $30 \mathrm{~min}$; finally, the absorbance at $515 \mathrm{~nm}$ was recorded. The DPPH solution with no added extract was used as control, and methanol was used as a blank. Usnic acid was dissolved in acetone to obtain a solution with a similar concentration as the lichen solutions. The concentration of the usnic acid solution was $0.2 \mathrm{mg} / \mathrm{mL}$. For each UBDE, the following dilutions were obtained: 1:1, 1:2, 1:3, 1:4, 1:5. The scavenger activity was calculated as follows:

$$
\text { Scavenging of DPPH }(\%)=100 \times[(\text { A control }- \text { A sample }) / \text { A control }]
$$

A control and A sample being the absorbance values at $515 \mathrm{~nm}$ for DPPH solution and UBDE solution.

All the determinations were completed in triplicate; the obtained data were registered as means $\pm \mathrm{SD}$ and analyzed using linear regression analysis with the Microsoft Excel software (Microsoft Corporation, Redmond, WA, USA).

\subsection{Evaluation of the Cytotoxic Activity by Brine Shrimp Lethality Assay}

Brine shrimp larvae were obtained by introducing the cysts of Artemia salina $\mathrm{L}$ for $24 \mathrm{~h}$, in a saline solution of $35 \%$, under conditions of continuous light and aeration. After hatching brine shrimp in the first larval stage (instar I), they were separated and introduced into experimental pots (with a volume of $1 \mathrm{~mL}$ ) in 2-3\% saline solutions [66]. For these tests, six stock solutions of usnic acid and five different UBDEs were prepared by solubilization in DMSO $0.1 \%$. Artemia salina L. larvae were not fed during the test period to not interfere with the tested extracts. This bioassay was valid for $24-48 \mathrm{~h}$, during which the larvae had embryonic energy reserves. Brine shrimp larvae were exposed to different usnic 
acid concentrations and various UBDE; they were evaluated periodically, recording the antennae movements and the larvae metamorphosis from the first stage to the second and third stages [67].

After $24 \mathrm{~h}$ of exposure, the death rate was the measurable parameter for quantifying larvae response to the various concentrations of usnic acid and UBDE. For control, 3\% saline solution and $0.1 \%$ DMSO in saline solution were used to evaluate solvents effect on Artemia salina L. For each concentration of usnic acid and UBDE, four repetitions were performed.

The statistical analysis of biological data, and the larvae mortality, was calculated as a mean for four repetitions \pm SD. One-way ANOVA, by Dunnett test, was used for evaluated experimental groups vs. negative control. Statistically significant differences were considered for $p$-values $<0.05$.

\section{Conclusions}

All Usnea barbata (L.) F.H. Wigg. extracts highlight antioxidant activity due to their secondary metabolites (usnic acid, polyphenols, and tannins) by reducing the free radicals. The water extract showed no cytotoxic activity on brine shrimp larvae. However, all the other UBDEs obtained in our study and the usnic acid proved high cytotoxicity on Artemia salina L. larvae.

Our study novelty consists of the comparative analysis of five dry extracts of $U$. barbata with the usnic acid. These extracts were obtained in five safe solvents, and the solubility of usnic acid increases from water to ethyl acetate. The objectives were to evaluate the extraction yield, the content of active phytoconstituents and their biological activities. The analysis of two opposite biological effects - the antioxidant activity (considered as cytoprotective) and the cytotoxic action-for optimal correlation with the metabolites content of each extract has been described. The obtained data could enrich the existing information in the scientific database, which must be constantly updated by quantifying $U$. barbata secondary metabolites responsible for antioxidant and cytotoxic activity.

These presented results create the premise for further studies focused on highlighting and quantifying the in vitro antitumor properties and deciphering the mechanisms of action of various $U$. barbata dry extracts on different human cell lines.

Supplementary Materials: The following are available online at https: / www.mdpi.com/article / 10.3390 / plants10050909/s1, Figure S1. Peak purity of UBDE in acetone; Figure S2. Peak purity of UBDE in ethyl acetate; Figure S3. Peak purity of UBDE in ethanol; Figure S4. Peak purity of UBDE in methanol; Figure S5. Peak purity of usnic acid standard solution $50 \mu \mathrm{g} / \mathrm{mL}$; Figure S6. Display for Figure 1 Figure 2 Figure 3 Figure 4 Figure 5; Figure S7. (a) UBDE in water, (b) UBDE in methanol, (c) UBDE in ethyl acetate, (d) UBDE in ethanol, (e) UBDE in acetone, (f) usnic acid standard solution $50 \mu \mathrm{g} / \mathrm{mL}$; Table S1. Peak-index values for UBDE in acetone, ethyl acetate, ethanol, methanol and reference solution (usnic acid in DMSO $50 \mu \mathrm{g} / \mathrm{mL}$ ); Table S2. Determination of the accuracy of the method.

Author Contributions: Conceptualization, V.P. and L.B.; methodology, L.B., A.P., V.S., T.C., D.R., I.E.C. and C.E.G.; software, V.S., T.C., D.R. and I.E.C.; validation, L.B., V.S., T.C. and C.E.G.; formal analysis, V.B.; investigation, A.C.; resources, V.P.; data curation, V.P., and G.V.; writing-original draft preparation, V.P.; writing—review and editing, V.P., L.B., D.G. and G.V.; visualization, C.E.G., G.V. and V.B.; supervision, G.V. and V.B.; project administration, V.B.; funding acquisition, V.P. All authors have read and agreed to the published version of the manuscript.

Funding: This work is supported by the project ANTREPRENORDOC, in the framework of Human Resources Development Operational Programme 2014-2020, financed from the European Social Fund under the contract number 36355/23.05.2019 HRD OP/380/6/13—SMIS Code: 123847.

Institutional Review Board Statement: Not applicable.

Informed Consent Statement: Not applicable. 
Acknowledgments: This study was performed in collaboration with the Research Centre of Instrumental Analysis SCIENT, 1E Petre Ispirescu Street, 77167 Tancabesti, Ilfov, Institute of Biological Research Iasi, branch of NIRDBS, and Department of Pharmacognosy, Phytochemistry, and Phytotherapy, Faculty of Pharmacy, Carol Davila University of Medicine and Pharmacy, Bucharest, Romania.

Conflicts of Interest: The authors declare no conflict of interest.

\section{References}

1. Poljsak, B.; Šuput, D.; Milisav, I. Achieving the balance between ROS and antioxidants: When to use the synthetic antioxidants. Oxid. Med. Cell. Longev. 2013, 2013, 956792. [CrossRef] [PubMed]

2. Saha, S.K.; Lee, S.B.; Won, J.; Choi, H.Y.; Kim, K.; Yang, G.M.; Dayem, A.A.; Cho, S.G. Correlation between oxidative stress, nutrition, and cancer initiation. Int. J. Mol. Sci. 2017, 18, 1544. [CrossRef] [PubMed]

3. Münzel, T.; Daiber, A. Environmental Stressors and Their Impact on Health and Disease with Focus on Oxidative Stress. Antioxid. Redox Signal. 2018, 28, 735-740. [CrossRef] [PubMed]

4. Pizzino, G.; Irrera, N.; Cucinotta, M.; Pallio, G.; Mannino, F.; Arcoraci, V.; Squadrito, F.; Altavilla, D.; Bitto, A. Oxidative Stress: Harms and Benefits for Human Health. Oxid. Med. Cell. Longev. 2017, 2017, 8416763. [CrossRef] [PubMed]

5. Aggarwal, V.; Tuli, H.S.; Varol, A.; Thakral, F.; Yerer, M.B.; Sak, K.; Varol, M.; Jain, A.; Khan, M.A.; Sethi, G. Role of reactive oxygen species in cancer progression: Molecular mechanisms and recent advancements. Biomolecules 2019, 9, 735. [CrossRef] [PubMed]

6. Godos, J.; Currenti, W.; Angelino, D.; Mena, P.; Castellano, S.; Caraci, F.; Galvano, F.; Rio, D.D.; Ferri, R.; Grosso, G. Diet and mental health: Review of the recent updates on molecular mechanisms. Antioxidants 2020, 9, 346. [CrossRef] [PubMed]

7. Daenen, K.; Andries, A.; Mekahli, D.; Van Schepdael, A.; Jouret, F.; Bammens, B. Oxidative stress in chronic kidney disease. Pediatr. Nephrol. 2019, 34, 975-991. [CrossRef]

8. Liguori, I.; Russo, G.; Curcio, F.; Bulli, G.; Aran, L.; Della-Morte, D.; Gargiulo, G.; Testa, G.; Cacciatore, F.; Bonaduce, D.; et al. Oxidative stress, aging, and diseases. Clin. Interv. Aging 2018, 13, 757-772. [CrossRef] [PubMed]

9. Dubois-deruy, E.; Peugnet, V.; Turkieh, A.; Pinet, F. Oxidative stress in cardiovascular diseases. Antioxidants $2020,9,864$. [CrossRef]

10. Halvorsen, B.L.; Holte, K.; Myhrstad, M.C.W.; Barikmo, I.; Hvattum, E.; Remberg, S.F.; Wold, A.B.; Haffner, K.; Baugerød, H.; Andersen, L.F.; et al. A systematic screening of total antioxidants in dietary plants. J. Nutr. 2002, 132, 461-471. [CrossRef]

11. Apel, K.; Hirt, H. Reactive oxygen species: Metabolism, oxidative stress, and signal transduction. Annu. Rev. Plant Biol. 2004, 55, 373-399. [CrossRef]

12. Lewis, N.G. Plants Phenolics. In Antioxidants in Higher Plants, 1st ed.; Alscher, R.G., Hess, J.L., Eds.; CRC Press: Boca Raton, FL, USA, 2017; pp. 135-171.

13. Goto, E. Environmental Stress and Secondary Metabolites. Shokubutsu Kankyo Kogaku 2019, 31, 7-20. [CrossRef]

14. Narita, S.; Saito, E.; Sawada, N.; Shimazu, T.; Yamaji, T.; Iwasaki, M.; Ishihara, J.; Takachi, R.; Shibuya, K.; Inoue, M.; et al. Dietary consumption of antioxidant vitamins and subsequent lung cancer risk: The Japan Public Health Center-based prospective study. Int. J. Cancer 2018, 142, 2441-2460. [CrossRef]

15. Agati, G.; Azzarello, E.; Pollastri, S.; Tattini, M. Flavonoids as antioxidants in plants: Location and functional significance. Plant Sci. 2012, 196, 67-76. [CrossRef]

16. Stevenson, D.E.; Hurst, R.D. Review Polyphenolic phytochemicals—Just antioxidants or much more? Cell Mol. Life Sci. 2007, 64, 2900-2916. [CrossRef]

17. Phương, D.L.; Thuy, N.T.; Long, P.Q.; Quan, P.M.; Thuy, T.T.T.; Minh, P.T.H.; Kuo, P.C.; Thang, T.D. Fatty acid, tocopherol, sterol compositions and antioxidant activity of three Garcinia seed oils. Rec. Nat. Prod. 2018, 12, 323-331. [CrossRef]

18. Wang, J.; Hu, S.; Nie, S.; Yu, Q.; Xie, M. Reviews on Mechanisms of in Vitro Antioxidant Activity of Polysaccharides. Oxid. Med. Cell. Longev. 2016, 2016, 5692852. [CrossRef]

19. Kosanić, M.; Ranković, B. Studies on antioxidant properties of lichen secondary metabolites. In Lichen Secondary Metabolites: Bioactive Properties and Pharmaceutical Potential; Ranković, B., Ed.; Springer International Publishing: Basel, Switzerland, 2015; pp. 105-125.

20. Fernández-Moriano, C.; Divakar, P.K.; Crespo, A.; Gómez-Serranillos, M.P. Antioxidant and cytoprotective potentials of Parmeliaceae lichens and identification of active compounds. An. Real Acad. Nac. Farm. 2015, 81, 164-178.

21. Paliya, B.S.; Bajpai, R.; Jadaun, V.; Kumar, J.; Kumar, S.; Upreti, D.K.; Singh, B.N.R.; Nayaka, S.; Joshi, Y.; Singh, B.N. The genus Usnea: A potent phytomedicine with multifarious ethnobotany, phytochemistry and pharmacology. RSC Adv. 2016, 6, 21672-21696.

22. Ramírez, I.; Araya, S.; Piovano, M.; Carvajal, M.; Cuadros-Inostroza, A.; Espinoza, L.; Garbarino, J.A.; Peña-Cortés, H. Lichen depsides and depsidones reduce symptoms of diseases caused by Tobacco Mosaic Virus (TMV) in tobacco leaves. Nat. Prod. Commun. 2012, 7, 603-606. [CrossRef]

23. Salgado, F.; Albornoz, L.; Cortéz, C.; Stashenko, E.; Urrea-Vallejo, K.; Nagles, E.; Galicia-Virviescas, C.; Cornejo, A.; Ardiles, A.; Simirgiotis, M.; et al. Secondary metabolite profiling of species of the genus usnea by UHPLC-ESI-OT-MS-MS. Molecules 2018, $23,54$. [CrossRef] 
24. Stocker-Wörgötter, E.; Cordeiro, L.M.C.; Iacomini, M. Accumulation of potential pharmaceutically relevant lichen metabolites in lichens and cultured lichen symbionts. In Studies in Natural Products Chemistry, 1st ed.; Atta-ur-Rahman, F.R.S., Ed.; Elsevier: Amsterdam, The Netherlands, 2013; Volume 39, pp. 337-380.

25. White, P.A.S.; Oliveira, R.C.M.; Oliveira, A.P.; Serafini, M.R.; Araújo, A.A.S.; Gelain, D.P.; Moreira, J.C.F.; Almeida, J.R.G.S.; Quintans, J.S.S.; Quintans-Junior, L.J.; et al. Antioxidant activity and mechanisms of action of natural compounds isolated from lichens: A systematic review. Molecules 2014, 19, 14496-14527. [CrossRef]

26. Su, Z.-Q.; Liu, Y.-H.; Guo, H.-Z.; Sun, C.-Y.; Xie, J.-H.; Li, Y.-C.; Chen, J.-N.; Lai, X.-P.; Su, Z.-R.; Chen, H.-M. Effect-enhancing and toxicity-reducing activity of usnic acid in ascitic tumor-bearing mice treated with bleomycin. Int. Immunopharmacol. 2017, 46, 146-155. [CrossRef]

27. Pérez-Torres, I.; Castrejón-Téllez, V.; Soto, M.E.; Rubio-Ruiz, M.E.; Manzano-Pech, L.; Guarner-Lans, V. Oxidative stress, plant natural antioxidants, and obesity. Int. J. Mol. Sci. 2021, 22, 1786. [CrossRef]

28. Poudel, M.; Rajbhandari, M. Phytochemical Analysis of Ampelopteris Prolifera (Retzius) Copeland. Nepal J. Sci. Technol. 2020, 19, 78-88. [CrossRef]

29. Zhong, Q.; Wei, B.; Wang, S.; Ke, S.; Chen, J.; Zhang, H.; Wang, H. The antioxidant activity of polysaccharides derived from marine organisms: An overview. Mar. Drugs 2019, 17, 674. [CrossRef]

30. Rabelo, T.K.; Zeidán-Chuliá, F.; Vasques, L.M.; dos Santos, J.P.A.; da Rocha, R.F.; Pasquali, M.A.; Rybarczyk-Filho, J.L.; Araújo, A.A.S.; Moreira, J.C.F.; Gelain, D.P. Redox characterization of usnic acid and its cytotoxic effect on human neuron-like cells (SH-SY5Y). Toxicol. In Vitro 2012, 26, 304-314. [CrossRef]

31. Ravaglia, L.M.; Gonçalves, K.; Oyama, N.M.; Coelho, R.G.; Spielmann, A.A.; Honda, N.K. In vitro radical-scavenging activity, toxicity against A. Salina, and Nmr profiles of extracts of lichens collected from Brazil and Antarctica. Quim. Nova 2014, 37, 1015-1021.

32. Iancu, I.M.; Bucur, L.A.; Schroder, V.; Mireșan, H.; Sebastian, M.; Iancu, V.; Badea, V. Phytochemical evaluation and cytotoxicity assay of lythri herba extracts. Farmacia 2021, 69, 51-58. [CrossRef]

33. Nunes, B.S.; Carvalho, F.D.; Guilhermino, L.M.; Van Stappen, G. Use of the genus Artemia in ecotoxicity testing. Environ. Pollut. 2006, 144, 453-462. [CrossRef] [PubMed]

34. Popovici, V.; Bucur, L.A.; Schröder, V.; Gherghel, D.; Mihai, C.T.; Caraiane, A.; Badea, F.C.; Vochița, G.; Badea, V. Evaluation of the cytotoxic activity of the Usnea barbata (L.) F. H. Wigg dry extract. Molecules 2020, 25, 1865. [CrossRef]

35. Kumar, K.; Mishra, J.P.N.; Singh, R.P. Usnic acid induces apoptosis in human gastric cancer cells through ROS generation and DNA damage and causes up-regulation of DNA-PKcs and $\gamma$-H2A.X phosphorylation. Chem. Biol. Interact. 2020, 315, 108898. [CrossRef]

36. Qi, W.; Lu, C.; Huang, H.; Zhang, W.; Song, S.; Liu, B. (+)-Usnic Acid Induces ROS-dependent Apoptosis via Inhibition of Mitochondria Respiratory Chain Complexes and Nrf2 Expression in Lung Squamous Cell Carcinoma. Int. J. Mol. Sci. 2020, 21, 876. [CrossRef]

37. Popovici, V.; Bucur, L.; Costache, T.; Gherghel, D.; Vochita, G.; Mihai, C.T.C.T.; Rotinberg, P.; Schroder, V.; Badea, F.C.F.C.; Badea, V.; et al. Studies on Preparation and UHPLC Analysis of the Usnea Barbata (L) F.H.Wigg Dry acetone extract. Rev. Chim. 2019, 70, 3775-3777. [CrossRef]

38. Meyer, B.N.; Ferrigni, N.R.; Putnam, J.E.; Jacobsen, L.B.; Nichols, D.E.; McLaughln, J.L. Brine Shrimp: A Convenient General Bioassay for Active Plant Constituents. Planta Med. 1982, 45, 31-34. [CrossRef]

39. Clarkson, C.; Maharaj, V.J.; Crouch, N.R.; Grace, O.M.; Pillay, P.; Matsabisa, M.G.; Bhagwandin, N.; Smith, P.J.; Folb, P.I. In vitro antiplasmodial activity of medicinal plants native to or naturalised in South Africa. J. Ethnopharmacol. 2004, 92, 177-191. [CrossRef]

40. Duman, D.C.; Aras, S.; Atakol, O. Determination of Usnic Acid Content in Some Lichen Species Found in Anatolia. J. Appl. Biol. Sci. 2008, 2, 41-44.

41. Dirar, A.I.; Alsaadi, D.H.M.; Wada, M.; Mohamed, M.A.; Watanabe, T.; Devkota, H.P. Effects of extraction solvents on total phenolic and flavonoid contents and biological activities of extracts from Sudanese medicinal plants. S. Afr. J. Bot. 2019, 120, 261-267. [CrossRef]

42. Sultana, B.; Anwar, F.; Ashraf, M. Effect of extraction solvent/technique on the antioxidant activity of selected medicinal plant extracts. Molecules 2009, 14, 2167-2180. [CrossRef]

43. Caprita, R.; Caprita, A. Chemical Methods for the Determination of Soluble and Insoluble Non-Starch Polysaccharides-Review. Sci. Pap. Anim. Sci. Biotechnol. 2011, 44, 81-84.

44. Jin, J.Q.; Rao, Y.; Bian, X.L.; Zeng, A.G.; Yang, G. De Solubility of (+)-usnic acid in water, ethanol, acetone, ethyl acetate and n-hexane. J. Solut. Chem. 2013, 42, 1018-1027. [CrossRef]

45. Maulidiyah, M.; Cahyana, A.H.; Suwarso, W.P. A New Phenolic Compound from Acetone Extract of Lichen Usnea flexuosa Tayl. Indones. J. Chem. 2011, 11, 290-294. [CrossRef]

46. Fernández-Moriano, C.; Gómez-Serranillos, M.P.; Crespo, A. Antioxidant potential of lichen species and their secondary metabolites. A systematic review. Pharm. Biol. 2016, 54, 1-17. [CrossRef] [PubMed]

47. Zugic, A.; Jeremic, I.; Isakovic, A.; Arsic, I.; Savic, S.; Tadic, V. Evaluation of anticancer and antioxidant activity of a commercially available $\mathrm{CO}_{2}$ supercritical extract of old man's beard (Usnea barbata). PLoS ONE 2016, 11, 0146342. [CrossRef] [PubMed]

48. Zhang, B.W.; Xu, J.L.; Zhang, H.; Zhang, Q.; Lu, J.; Wang, J.H. Structure elucidation of a polysaccharide from Umbilicaria esculenta and its immunostimulatory activity. PLoS ONE 2016, 11, 0168472. [CrossRef] [PubMed] 
49. Odabasoglu, F.; Cakir, A.; Suleyman, H.; Aslan, A.; Bayir, Y.; Halici, M.; Kazaz, C. Gastroprotective and antioxidant effects of usnic acid on indomethacin-induced gastric ulcer in rats. J. Ethnopharmacol. 2006, 103, 59-65. [CrossRef] [PubMed]

50. Bian, X.; Jin, J.; Ding, D.; Zhang, H. Study on the scavenging action of polysaccharide of Usnea longissima to oxygen radical and its anti-lipi peroxidation effects. Zhong Yao Cai 2002, 25, 188-189.

51. Ranković, B.; Kosanić, M.; Stanojković, T.; Vasiljević, P.; Manojlović, N. Biological activities of toninia candida and usnea barbata together with their norstictic acid and usnic acid constituents. Int. J. Mol. Sci. 2012, 13, 14707-14722. [CrossRef]

52. Odabasoglu, F.; Aslan, A.; Cakir, A.; Suleyman, H.; Karagoz, Y.; Halici, M.; Bayir, Y. Comparison of antioxidant activity and phenolic content of three lichen species. Phyther. Res. 2004, 18, 938-941. [CrossRef]

53. Brisdelli, F.; Perilli, M.; Sellitri, D.; Piovano, M.; Garbarino, J.A.; Nicoletti, M.; Bozzi, A.; Amicosante, G.; Celenza, G. Cytotoxic activity and antioxidant capacity of purified lichen metabolites: An in vitro study. Phyther. Res. 2013, 27, 431-437. [CrossRef]

54. Kim, M.; Lee, W.; Park, J.; Kim, W.; Jo, S.; Kim, W.; Kim, C.; Park, H.; Lee, G.; Park, J. Advanced tracking system of multiple Artemia and various behavioral endpoints for ecotoxicological analysis. Ecol. Indic. 2020, 116, 106503. [CrossRef]

55. Alahmadi, A.A. Usnic acid biological activity: History, evaluation and usage. Int. J. Basic Clin. Pharmacol. 2017, 6, 2752-2759. [CrossRef]

56. Joshi, D.R.; Adhikari, N. An Overview on Common Organic Solvents and Their Toxicity. J. Pharm. Res. Int. 2019, 28, 1-18. [CrossRef]

57. Mafole, T.C.; Aremu, A.O.; Van Staden, J.; Solhaug, K.A.; Beckett, R.P.; Finnie, J.F. Effect of seasonal variation on the biological activities and lichen metabolites in Usnea undulata and Heterodermia speciosa found in KwaZulu-Natal Province, South Africa. S. Afr. J. Bot. 2016, 103, 324. [CrossRef]

58. Bjerke, J.W.; Elvebakk, A.; Domínguez, E.; Dahlback, A. Seasonal trends in usnic acid concentrations of Arctic, alpine and Patagonian populations of the lichen Flavocetraria nivalis. Phytochemistry 2005, 66, 337-344. [CrossRef]

59. Prasad, S.B.; Sharma, A. Standardisation of convolvulus pluricaulis choisy herbs collected from Jalandhar, Punjab. Int. J. Pharmacogn. Phytochem. Res. 2016, 8, 1412-1416.

60. Pedjie, N. Rapid UHPLC Determination of Common Preservatives in Cosmetic Products. LCGC Asia Pac. 2010, $13,45$.

61. Maisetta, G.; Batoni, G.; Caboni, P.; Esin, S.; Rinaldi, A.C.; Zucca, P. Tannin profile, antioxidant properties, and antimicrobial activity of extracts from two Mediterranean species of parasitic plant Cytinus. BMC Complement. Altern. Med. 2019, 19, 82. [CrossRef]

62. Nasser, M.; Cheikh-Ali, H.; Hijazi, A.; Merah, O.; Al-Rekaby, A.E.A.N.; Awada, R. Phytochemical profile, antioxidant and antitumor activities of green grape juice. Processes 2020, 8, 507. [CrossRef]

63. Galvão, M.A.M.; de Arruda, A.O.; Bezerra, I.C.F.; Ferreira, M.R.A.; Soares, L.A.L. Evaluation of the Folin-Ciocalteu Method and Quantification of Total Tannins in Stem Barks and Pods from Libidibia ferrea (Mart. ex Tul) L. P. Queiroz. Braz. Arch. Biol. Technol. 2018, 61, 1-20. [CrossRef]

64. Tikhomirova, E.A.; Sorokina, A.A.; Bubenchikova, V.N.; Kostikova, E.N.; Zhilkina, V.Y.; Bessonov, V.V. Chemical composition and content of polysaccharides from the yellow iris (Iris pseudacorus L.) rhizomes. Pharmacogn. J. 2020, 12, 1012-1018. [CrossRef]

65. Cakmak, K.C.; Gülçin, İ. Anticholinergic and antioxidant activities of usnic acid-an activity-structure insight. Toxicol. Rep. 2019, 6, 1273-1280. [CrossRef]

66. Libralato, G.; Prato, E.; Migliore, L.; Cicero, A.M.; Manfra, L. A review of toxicity testing protocols and endpoints with Artemia spp. Ecol Indic. 2016, 69, 35-49. [CrossRef]

67. Solis, P.N.; Wright, C.W.; Anderson, M.M.; Gupta, M.P.; Phillipson, J.D. A microwell cytotoxicity assay using Artemia salina (brine shrimp). Planta Med. 1993, 59, 250-252. [CrossRef] 